\title{
Nuwun Sewu Culture As Local Activity In The Formation Of Community Characters
}

\author{
Sukron Mazid $^{1}$, Achmad Busrotun Nufus ${ }^{2}$, Delfiyan Widiyanto ${ }^{3}$, Danang Prasetyo ${ }^{4}$ \\ \{sukronmazid@untidar.ac.id ${ }^{1}$, busro@untidar.ac.id ${ }^{2}$,delfiyanwidiyanto@untidar.ac.id ${ }^{3}$, \\ danangprasetyo@stipram.ac.id $\left.{ }^{4}\right\}$ \\ Tidar University, Indonesia ${ }^{1}$ \\ Tidar University, Indonesia ${ }^{2}$ \\ Tidar University, Indonesia ${ }^{3}$
}

\begin{abstract}
The specific purpose of this study is to identify the culture of nuwun sewu as a character building in social life. Javanese people used to always use the nuwun sewu habit in their daily life as a tradition of upholding politeness. Javanese people are known for their manners and their advantages of respecting others. Nuwun sewu culture as local wisdom and shaping the character of the community becomes an example and culture in behaving. This research applied descriptive qualitative approach. The results showed that first, the social environment of the community influences the formation of the character culture of a civilised society through modeling. Second, the educational environment is influential in providing understanding and knowledge of citizen behavior in building the character of society by means of culture.
\end{abstract}

Keywords: nuwun sewu culture, local wisdom, character

\section{Introduction}

Indonesia is renowned for its cultural diversity. The statistics show that there are 819 non-material cultural heritages throughout Indonesia in the forms of tradition and spoken expression, customs, rituals, celebration, knowledge, and behaviour about the universe, performing arts, and traditional crafts since 2013-2018. Java Island particularly has 98 nonmaterial cultural heritages: 40 in West Java, 22 in Central Java, and 36 in East Java.[8].

Nuwun Sewu culture is behaviour and spoken culture in Java Island which comes from human's activities and behaviours. Van Peursen explained that culture could be related to human's activities such as working, feeling, thinking, initiating, and creating. [14] Culture is resulted from a human's sense of intent to live in purpose and dignity.

Various ethnic groups, customs, and culture in Indonesia are valuable things. However, these diversities may lead to social problems such as violence against women and children which is a criminal case and contrary to the Pancasila moral values. National Commission on Violence against Women and Children revealed in 2018; there are 348,446 cases of violence against women in 34 provinces in Indonesia.[17] The cases increase in numbers and become more complex and complicated. Violence against women and children is problematic as they do not happen accidentally and cannot be solved unilaterally.[11] 
The violence victims case is not only the poor and uneducated people. [23] The violence cases need special treatment and solution to prevent and solve the problems through education, politics, religion, and socio-cultural approach. Nuwun sewu culture is expected to be able to prevent and to solve any violence cases in Indonesia.

Magelang city is located in the primary access between Semarang and Yogyakarta. As a 'transit city', Magelang is an attractive small city with historical and cultural values that attract domestic and foreign tourists. Magelang is famous for its tourism spots such as Borobudur temple and its culinary and local wisdom. The massive growth of information, technology, and foreign culture has affected the traditional culture to fade away slowly.

Besides the economics factors, globalisation also has some negative impacts such as selfishness, individualism, and the loss of ethics, moral, and cultural values. Social problems, such as violence against women, children, and family, start to grow. These are the negative impacts of global culture. DPMPAPKB Magelang has released the data of the violence cases against women and children during 2016-2019 as shown in the following table:

Table 1. Violence Cases in Magelang

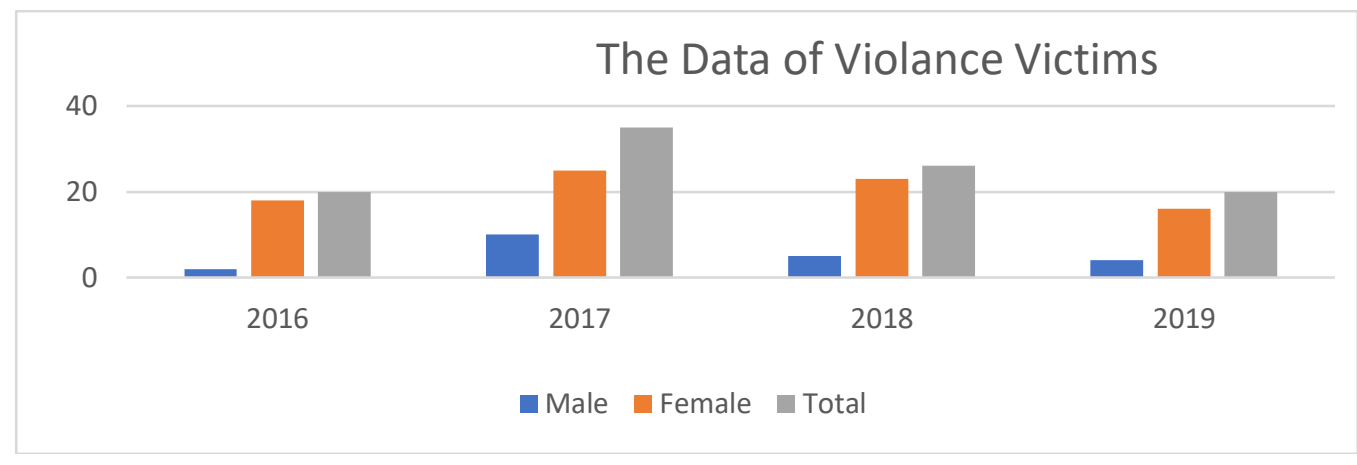

It can be seen from the data that the numbers of violence victims tend to be static without a significant decrease. Yulis, the head of division at Women and Children Protection, said that the violence cases are static in the last four years. Violence and physical abuse to women and children happen frequently. Therefore, strategies and methods to solve the problems are needed in social life and how to behave.[16] Religious, character, moral values, and local wisdom should be implemented to prevent negative behaviours. The tradition of nuwun sewu culture in Javanese people can be one of the barometers to prevent and avoid acts of violence and negative behaviours because it reflects respect and modesty as good examples for society.

It is crucial to preserve and implement nuwun sewu culture as the preventive actions toward Magelang city citizens' negative behaviours. The kinds of local wisdom observed here are culture, natural condition and society's social elements that can shape the Magelang community's character.[9] By maintaining, caring, preserving the ancestral cultures, nuwun sewu cultures as local wisdom, people are expected to have the right attitude and manner as their characters. A person with character means a person who has personality, behaviour, nature or character.[13] This study is aimed to identify the role of nuwun sewu culture in society, especially for the young generation. This study urges the existence of nuwun sewu culture in shaping people's character, particularly in Magelang city. The scope of this study is the implementation of local wisdom to shape social characters among the people, including social and education. 


\section{$2 \quad$ Methodology}

It is descriptive qualitative research. Qualitative research is a series of practices in interpreting material from various representations, including various field notes, interviews, conversations, photos, recordings, and information-giving notes.[2] Ethnographic method was used in this research to explain the relationship between categories. Endraswara (2015) stated that ethnography is a study of society's life and culture.[5] The research was conducted in Magelang City from February to September 2020. The purposive sampling was used in this research and it was adjusted to the research's objectives.[19] Research subjects were determined based on the person who is considered to know the most about the required information. The subjects on this research were Mrs Euis Maryam, the Head of Social Service Rehabilitation of Magelang City; Mrs. Anik Herawati, the Head of Social Affairs, North Magelang District; Mrs. Eva Yanti, the Head of Social Affairs, Central Magelang District; Fuad, the officer of Child and Woman Protection of Magelang City; Kyai Zainuddin, Religious Figure of Magelang City; Wahyu Utomo, Buddhist Figures of Magelang City; Bambang Eka Prasetya, the cultural practitioners in Magelang and Ahmad Akrom, the junior high school teacher of SMP 1 Magelang City. The data collection techniques used in this research were in-depth interview, observation and document study. The researcher was the primary research instrument. The researcher was also the planner who determined the research's focus, selected informants, collected the data, interpreted the data, drew temporary conclusions, and analysed it.[4] This research applied the triangulation of technique and source to test the validity of the data. Then, the data were analysed by using data analysis by Miles and Huberman (1984) such as data reduction, data categorisation and unitisation, data display, and conclusion drawing verification.[10]

\section{$3 \quad$ Finding and Discussion}

The plural characteristics of the citizens of Magelang City certainly leads the different cultures and characters, both in speaking and behaving. However, the values of local wisdom and Javanese culture still adhere to the citizens. It can be seen from their attitude in their daily life that uphold Javanese manner and ethics. The community has a role and function in daily life activity which are related to the nuwun sewu culture as forming a community's character both in the community and education. The several roles that shape society to behave and act are as follows.

\subsection{Community Environment}

The moral formation, especially for the young generation, is an urgent part to be realised to create a better community, a society that is ready and able to face regional and global challenges.[3] Community has a significant role in building the character of the young generation. The most crucial thing in character building is starting from the family, especially parents. Parents are the first educators for their children, especially for the moral formation in everyday life. By considering the family needs, their power can help ensure security in families when there are resistance, reluctance, or fear.[12] Family is the central controller of their children life. Then, the community environment is also the most critical part of building children's character. Since social interaction begins in the community, it can shape the community's attitude and behaviour in their life. Likewise, neighbours, friends and community 
leaders have an enormous influence in shaping behaviour as well. Several positive and negative values can be obtained in the community as a provision for life behaviour. Many residents become role models because they provide good examples in the social community. The following are examples of behaviour that the community can apply:

a. Familiarise themselves with the cooperation and community service, such as cleaning the yard, cleaning drains, planting the tree in house yards.

b. Familiarise children with not littering and spitting on the road, destroying or scribbling on public facilities.

c. Reprimand children for doing bad deeds.

d. Preserve the local wisdom values as a basis for behaviour in society.

e. Greetings and participate in social activities and be active in the social environment.

The wider community environment significantly influences the successful inculcation of values in shaping attitudes and behaviour. Community participation in instilling attitudes and behaviour is very closely related to change the way people perceive them in social interaction. The attitude formation has never been done if it is not started since the early stages. The right and responsive ways to provide a good habit in the community are respecting, caring, and participating actively. According to Suyitno, individual character building is a function of all the individual potential in cognitive, affective, conative, and psychomotor aspects. In the context of socio-cultural interactions, character building should be taught in the family, school and community and it should last throughout life[21].

Humans have intellectual, moral, and spiritual skills. In this case, if a conducive and suitable environment supports it, it will shape good attitudes and behaviour. The young generation with good attitudes will make a comfortable environment in the future. The heterogeneous citizens of Magelang City certainly have an impact on the behaviour of its residents. One of the behaviour is related to politeness in community life, such as saying nuwun sewu (Javanese culture) or excuse me. It gives an impact on noble character formation. Nuwun Sewu in the Javanese community forms the character of the community. The young generation who said nuwun sewu is the one who has noble ethics based on Javanese culture. The word nuwun sewu shows that young generations have good manners and will not be labelled as brutal, uncivilised, naughty or anarchist teenagers. It can also be said that nuwun sewu culture becomes the convention in shaping the good character of the community.

\subsection{Educational Environment}

In the family, children will be accustomed to "accepting what it is" in implementing an act or attitude; meanwhile, something becomes "absolute" at school. Therefore, the school must educate the students to be a scholar. It shows that school has an enormous influence in shaping the children's mindset and character, but it is not easily achieved without any effort. Becoming a good educator requires exemplary behaviour and consistency of exemplary behaviour. A good educator is not only good at saying something but also useful in their behaviour.

As the places of teaching and learning process, schools are not just a place for "transfer of knowledge". Fraenkel mentioned that schools are not merely places where teachers convey knowledge through various subjects. Schools are the institutions for the value-oriented enterprise learning process.[6] Character building is one of the values of education. Schools are institutions responsible for enriching a nation's life, not only producing competent students in science, technology, and arts but also in character. Schools as educational institutions certainly have a very strategic role in instilling character values in students. Therefore, educators must provide an example and cultivate character value in schools. A good model is fundamental to 
overcome character problems and dramatically contributes to educating and building the character.[15]

There are several formal and informal education in Magelang city. Furthermore, there is a military academy (AKMIL) as well. There are many levels of formal education in Magelang city, i.e. elementary school until university level. Meanwhile, Magelang city also has informal education such as TPA and Islamic boarding school. In addition to cultural sites and rites, those educations create religious, honest, discipline and responsible community. Education and culture have an impact on citizens' attitudes and behaviour. They become an educated citizen through education and culture. Moreover, the existence of a government university in Magelang city can give a significant impact as well to the community. The development of formal and informal education in Magelang city provides a blessing to the community to educate their young generation well. Nuwun sewu culture will be useful to be instilled in children to form a good character in the family, community and educational environment. To achieve children's good character, support from all partihes, especially parents, teacher, and community, is needed.

\subsection{Nuwun Sewu Culture Forms Community Character}

Nuwun sewu is a sentence that Javanese often use to respect the elderly. This culture is a type of courtesy in attitude and behaviour used by the young generation to the elderly. The relationship between culture and sustainability also involves culture more fundamentally. The value systems and symbolic universe shape civilisation's orientation, referred to as "culture of sustainability".[7] Nuwun Sewu is also local wisdom for the Javanese community in doing the activities and acting as an expression of respect for the elderly. Local wisdom is often associated with local communities. In other languages, it is conceptualised as local wisdom, local knowledge, or local genius. In addition, people will be guided by various kinds of things which essentially have good and bad values in their activities.[20] Local wisdom appears as a guard or filter of the global climate that affects human life. [22]

As stated by Pak Akrom, a teacher ats SMP 1 Magelang, Nuwun Sewu is local wisdom that teaches ethics and manners. Ibu Eva also emphasised this as the Head of Empowerment of Central Magelang district that ethics will be formed if nuwun sewu culture is instilled since the early age. The Javanese always prioritises manners such as nuwun sewu culture since it is very influential in life. Agung Jaya, a vocational high school student in Magelang City, stated that nuwun sеwи culture makes people have manners and ethics. Globalisation has an impact on young people's dressing, socialising, behaving, saying and acting. Schools become institutions that produce students who have intellectual, moral and spiritual skills. Kyai Zainudin, a cleric figure in Magelang city, stated that moral is the most crucial thing in social life.

Nuwun Sewu culture, which has begun to be abandoned, needs to be preserved and practised as a habit. Nuwun Sewu culture can uphold the value of local wisdom and shape community members' character to be good citizens and have noble character. Indeed, the current of globalisation affects everything. The globalisation trends nowadays are the emergence of new information technology, intensification of transnational and translocation dynamics, and the strengthening of the presence and voice of certain types of socio-cultural diversity. [18] It means that a diverse, globalised culture allows shifting local cultures. The community environment that teaches socio-cultural interaction of the nuwun sewu culture fosters an attitude of humility, honesty, cooperation, civilisation, and responsibility. The religious environment of Magelang community also fosters attitude, religion, tolerance, and respect. In short, nuwun sewu culture, which is upheld as a simple behaviour in speaking and acting, increases a civilised society. The educational environment in Magelang shapes the intelligent, tough, caring, disciplined and responsible community. 
Nuwun sewu is a simple word but has a deep meaning. Children who taught that culture would grow with good moral. Ibu Evi, the Head of the Empowerment Section of North Magelang District, stated that nuwun sewu culture is simple but have tons of meanings, and it can shape the children's attitude. One of Magelang city citizens, Hanif, also supported that statement, who stated that the word nuwun sewu or nderek langkung or excuse me has good meaning and influence to shape the attitude. Nuwun sewu can form the intelligent, religious, tough, caring, honest and responsible citizens of society so that nuwun sewu culture shapes the community's character. Nuwun sewu culture needs to be preserved and practiced as a habit.

The theory of practice urged by Pierre-Felix Bourdieu was very influential in the development of social science. In his theory, Bourdieu outlines three keywords in each actor's life, namely, habitus, capital, and field. Bourdieu's social practice composition can be expressed by the equation: $($ Habitus X Capital $)+$ Field = Practice. $[1]$



Fig. 1. Bourdieu's Social Practice Composition

Nuwun sewu culture is a theory of practice in the social life of Javanese society in respecting others. One of Bourdieu's theories makes a sustainable life cycle, where the identity that arises in the conscience becomes the capital in attitude and behaviour. In conclusion, the habitus is the result of the internalisation of the social world structure. Habitus is a historical product formed after humans born and interacted with society in a particular space and time. In Pierre Bourdieu's theory, community environment, educational environment, social activities, and work need to be practiced so that the culture of nuwun sewu becomes a tradition and habit. This recommendation can shape the character of the community. The pattern proposed by Bourdieu is a procedure of attitude and behaviour in a small example. However, it will have a significant impact on daily life, especially in shaping the attitudes and character of Magelang city community. The internalisation of local wisdom values with a noble purpose in social life, in this case nuwun sewu culture, becomes the design for community members' character building.

\section{Conclusion}

Based on the results and discussion, it can be concluded that nuwun sewu culture as local wisdom that has been believed for a long time can shape the characters of the local people. Society upholds the Javanese values in their interactions. Nuwun sewu as local wisdom has moral values to shape the character of the society. The Magelang people's religious environment 
has grown some good characters such as respect, tolerance, care, modesty, and democratic. There are many formal and non-formal education institutions in Magelang, which contribute to shaping a smart, strong, care, and responsible society. Good education value can collaborate academic and local wisdom such as in nuwun sewu culture to encourage moral values such as smart, honest, and responsible. Therefore, it is essential to implement the nuwun sewu culture as a tradition to shape a well-mannered and civilised society.

Nuwun sewu culture written in this research is developed and added the previous researches. Therefore, this research's uniqueness is the meaning of nuwun sewu itself as Javanese people's tradition, especially Magelang City. The researcher tries to see from a different point of view so that this research can be used as further reference for other researchers who will explore and re-examine the culture of Nuwun Sewu as the basis for local wisdom to shape the character of Javanese society, especially in Magelang. Thus, this research is expected to become a new discourse in socio-cultural science. It needs to be explored deeper and reaffirmed as a tradition in other areas that have regional meanings or sayings that contain cultural acts that can strengthen the nation's character.

\section{References}

[1] M. Siregar, “Teori 'Gado-gado’ Pierre-Felix Bourdieu,” An1mage Jurnal Studi Kultural, vol. 1, no. 2, pp. 79-82, 2016.

[2] J. W. Creswell, Penelitian kualitatif \& desain riset: memilih diantara lima pendekatan. Yogyakarta: Pustaka Pelajar, 2015.

[3] Ubpkarawang.ac.id. [Online]. Available: http://journal.ubpkarawang.ac.id/index.php/ PPKn/article/view/267.

[4] A. R. Djaelani, "Teknik Pengumpulan Data dalam Penelitian Kualitatif," PAWIYATAN, vol. 20, no. 1, 2013.

[5] S. Endraswara, Etnologi Jawa. Yogyakarta: CAPS (Center for Academic Publishing), 2015.

[6] J. R. Fraenkel, How to teach about values: An analytic approach. Prentice-Hall, 1977.

[7] S. Kagan, A. Hauerwaas, V. Holz, and P. Wedler, "Culture in Sustainable Urban Development: Practices and Policies for Spaces of Possibility and Institutional Innovations,," City, Culture and Society, vol. 13, no. September, pp. 32-45, 2018.

[8] K. P. Kebudayaan, "Statistik Kebudayaan 2019," Jenderal Sudirman Senayan, Jakarta, vol. 10270, 2019.

[9] S. Mazid, D. Prasetyo, and F. Farikah, "NILAI NILAI KEARIFAN LOKAL SEBAGAI PEMBENTUK KARAKTER MASYARAKAT,” Jurnal Pendidikan Karakter, vol. 10, no. 2, 2020.

[10] M. B. Miles and A. M. Huberman, Qualitative Data Analysis : Handout'. A Sourcebook of New Methods. California: SAGE publications Inc, 1984.

[11] K. U. Noer, "Mencegah Tindak Kekerasan pada Anak di Lembaga Pendidikan," Sawwa J. Studi Gend., vol. 14, no. 1, p. 47, 2019.

[12] L. Olszowy, P. G. Jaffe, M. Dawson, A.-L. Straatman, and M. D. Saxton, "Voices from the Frontline: Child Protection Workers' Perspectives on Barriers to Assessing Risk in Domestic Violence Cases,', Children and Youth Services Review, Elsevier, vol. 116, no. C, 2020.

[13] "Pendidikan Karakter Dan Pengintegrasiannya Dalam Pembelajaran.” pp. 1-14, 2008. 
[14] Van Peursen (Terjemahan Oleh Dick Hartoko. Yogyakarta: Kanisius, 1985.

[15] D. Prasetyo and M. Marzuki, "PEMBINAAN KARAKTER MELALUI KETELADANAN GURU PENDIDIKAN KEWARGANEGARAAN DI SEKOLAH ISLAM AL AZHAR YOGYAKARTA,” J. pendidik. karakter, vol. 6, no. 2, 2016.

[16] R. Dokumentasi, Data DPMPAPKB Kota Magelang. 2020.

[17] M. R. A. A. Farid, "Kekerasan terhadap Perempuan dalam Ketimpangan Relasi Kuasa: Studi Kasus di Rifka Annisa Women’s Crisis Center," Sawwa: Jurnal Studi Gender, vol. 14, no. 2, pp. 175-190, 2019.

[18] S. Sassen, "The city: Its return as a lens for social theory," City Cult. Soc., vol. 1, no. 1, pp. 3-11, 2010.

[19] Sugiyono, Metode Penelitian Pendidikan : Pendekatan Kuantitatif, Kualitatif, Dan R\&D. Bandung: Alfabeta, 2018.

[20] S. Suparmini, S. Setyawati, and D. R. S. Sumunar, "Pelestarian Lingkungan Masyarakat Baduy Berbasis Kearifan Lokal,” Jurnal Penelitian Humaniora, vol. 18, no. 1, pp. 8-22, 2013.

[21] I. Suyitno, "Pengembangan pendidikan karakter dan budaya bangsa berwawasan kearifan lokal," Jurnal pendidikan karakter, vol. 1, 2012.

[22] W. Wagiran, "Pengembangan Karakter Berbasis Kearifan Lokal Hamemayu Hayuning Bawana (Identifikasi Nilai-Nilai Karakter Berbasis Budaya," Jurnal Pendidikan Karakter, vol. 3, no. 3, pp. 329-339, 2012.

[23] S. Wimbarti, "Pengukuran Kebutuhan untuk Perancangan Intervensi Sosial dan Penurunan Resiko Tindak Kekerasan dalam Keluarga di Daerah Istimewa Yogyakarta," Jurnal Psikologi, vol. 33, no. 2, pp. 121-132, 2012. 